\title{
Rekomendasi Satgas Imunisasi
}

\author{
Sri Rezeki S Hadinegoro, Soedjatmiko
}

\begin{abstract}
Menghadapi masalah kesehatan anak dunia, Indonesia tidak dapat berdiam diri namun harus turut berpartisipasi aktif. Pakar WHO menegaskan bahwa dalam upaya pencegahan penyakit infeksi, dua hal yang harus menjadi perhatian utama ialah penyediaan air bersih dan imunisasi. Munculnya resistensi antibiotik pada beberapa mikroorganisme, keadaan imunokompromais, peningkatan kesehatan anak dengan risiko tinggi, telah memicu para ahli memalingkan arah untuk mencapai upaya pencegahan yang paripurna. Dalam satu dasa warsa terakhir, imunisasi telah mengalami perkembangan yang sangat pesat seiring dengan kemajuan teknik rekayasa genetika dan biomolekuler. Masuknya vaksin baru sebagai hasil teknologi modern yaitu vaksin influenza trivalen (TIV) dan vaksin pneumokokus (PCV7) memerlukan panduan penggunaannya yang dituangkan dalam Rekomendasi Satgas Imunisasi IDAI.
\end{abstract}

Kata kunci: rekomendasi, pneumococcus vaccine 7 valent (PCV7), trivalent influenza vaccine (TIV).

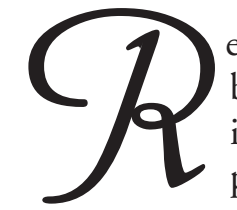

ekomendasi Satgas IDAI dibuat berdasarkan besaran masalah penyakit influenza (A dan B) dan infeksi pneumokokus invasif (invasive pneumococcus disease=IPD), imunogenisitas \& efektifitas kedua vaksin, aman dipergunakan pada bayi $\&$ anak, memperkuat program imunisasi nasional, dan kedua vaksin tersebut telah beredar secara resmi di Indonesia.

Rekomendasi pemberian vaksin influenza pada anak sehat berguna untuk menghadapi pandemik

Alamat korespondensi:

Prof Dr dr Sri Rezeki S Hadinegoro Sp.A(K),

Dr Soedjatmiko MSi., Sp.A(K)

Satgas Imunisasi Ikatan Dokter Anak Indonesia, Gedung IDAI,

Departemen IKA FKUI-RSCM. Jl. Salemba 6 Jakarta 10430. Tilp 21.3148610, 3100674. Fax 21.3913982.

E-mail: ppidai@idai.or.id. Website: www.idai.or.id influenza dan menurunkan penyebaran kasus. WHO tahun 2004 telah membuat panduan regional maupun nasional di seluruh negara di dunia. Persiapan ini perlu dilakukan sebagai pelayanan esensial dan mengurangi beban sosial ekonomi pada pandemi. Pandemi influenza akan terjadi apabila virus influenza baru timbul. Tidak satu manusiapun yang kebal terhadap virus baru tersebut, sehingga akan menyebabkan epidemi di seluruh dunia dan diramalkan dapat membunuh sangat banyak orang. Saat ini epidemi dapat terjadi sangat cepat di seluruh dunia. Virus baru diramalkan akan timbul apabila terjadi re-assortment antara virus manusia ( $\mathrm{H} 3 \mathrm{~N} 2$ atau $\mathrm{H} 3 \mathrm{~N} 1)$ dengan avian flu (H5N1). Maka dengan pemberian vaksinasi influenza manusia, diharapkan re-assortment tidak terjadi.

Rekomendasi penggunaan vaksin pneumokokus dan rekomendasi penggunaan vaksin influenza ini telah diserahkan pada Pengurus Pusat IDAI untuk disebarluaskan. 
Sari Pediatri, Vol. 8, No. 1, Juni 2006

\section{Rekomendasi Satgas Imunisasi IDAI Penggunaan vaksin Influenza pada anak}

Epidemiologi \& burden of disease influenza pada anak

- Diperkirakan sekitar 20\% anak-anak dan 5\% dewasa di seluruh dunia mengalami infeksi influenza $A$ atau $B$ yang simtomatik setiap tahun.

- Pada influenza demam lebih sering terjadi dibandingkan dengan infeksi virus respiratorius lainnya. Pada anak, komplikasi influenza lebih sering terjadi daripada dewasa; seperti demam tinggi (hiperpireksia), lebih banyak dijumpai kejadian rinitis, otitis media, manifestasi gastrointestinal, kejang demam, bronkiolitis, miositis, pneumonia, otitis media, dan ensefalopati.

- Dari jumlah anak yang dirawat karena menderita influenza, terbanyak berumur di bawah 12 bulan. Anak mempunyai risiko tinggi terhadap morbiditas dan mortalitas akibat influenza seperti kelompok lansia 50-64 tahun. Walaupun demikian, infection rates pada anak terbanyak terjadi pada kelompok usia sekolah, sehingga mudah menularkan kepada saudara serumah atau temannya.

- Penyakit penyerta terbanyak pada anak yang dapat diperberat oleh influenza adalah asma, penyakit jantung bawaan, penyakit defisiensi imun, keganasan, penyakit kardio-pulmonal, penyakit ginjal kronik, hemoglobinopati dan kelainan metabolik.

- Data surveilans dilakukan oleh US Naval Medical Research (NAMRU) dan Lembaga Penelitian dan Pengembangan Kesehatan (Litbangkes) tahun 1999-2003, dari 3079 spesimen apusan nasal dan farings yang dikumpulkan dari 1544 subjek. Didapatkan infeksi influenza pada 172 subjek $(11,1 \%)$ dari penderita influenza like illness (ILI). Influenza A (H1N1 dan (H3N2) serta virus B ditemukan pada semua tempat penelitian. Puncak prevalensi cenderung terjadi pada musim hujan.

\section{Perubahan antigenik virus influenza}

Virus influenza terdiri dari serotipe A, B dan C; namun yang sering menimbulkan wabah adalah influenza $\mathrm{A}$ dan B. Antigen permukaan terdiri dari HA (hema- glutinin antigen) dan NA (neuraminidase antigen) yang akan menentukan subtipe virus influenza. Hemaglutinin berfungsi mengikat virus pada permukaan sel, merupakan antigen paling penting untuk berkembangnya kekebalan.

- Pengaruh virus influenza terhadap terjadinya wabah disebabkan karena sifat virus influenza yang dapat menyebabkan viral shift \& viral drift. Pada antigenic drift: terjadi perubahan kecil HA atau NA, yang merupakan mutasi asam amino, dapat terjadi setiap 1 atau beberapa tahun dalam satu subtipe. Perubahan ini tidak menghasilkan subtipe baru. Namun dapat menyebabkan terjadinya epidemi (wabah). Sedangkan antigenic shift merupakan variasi genetik mayor pada HA dan/atau NA mengakibatkan munculnya sebuah virus "baru". Terhadap virus "baru" tersebut tidak ada kekebalan dalam populasi sehingga dapat menyebabkan pandemik setiap 10 to 40 tahun.

- Virus influenza cenderung mengadakan perubahan pada hemaglutinin sehingga menyebabkan hilangnya kekebalan akibat vaksinasi influenza. Oleh karena itu, galur (strain) vaksin harus disesuaikan setiap musim untuk mendapatkan galur terbaru yang bersirkulasi.

\section{Alasan Pemberian Vaksin Influenza pada Anak}

- Vaksin influenza tahunan (annual influenza vaccine) sangat dianjurkan untuk diberikan pada anak dengan risiko tinggi terjadinya infeksi influenza berat serta komplikasinya.

- Terjadinya peningkatan risiko perawatan pada anak yang menderita influenza.

- Pada beberapa negara, telah dianjurkan memberikan vaksin influenza pada anak sehat berumur 6-23 bulan, baik untuk mengurangi risiko terkena infeksi, mengurangi risiko penularan dari orang lain, dan mengurangi penularan kepada orang dewasa. 


\section{Vaksin influenza}

Vaksin yang tersedia berisi dua subtipe A yaitu H3N2 dan $\mathrm{H} 1 \mathrm{~N} 1$, serta virus tipe B. Vaksin influenza trivalen tersebut diproduksi dua kali setahun, berdasarkan perubahan pada galur influenza yang bersirkulasi.

- WHO Global Influenza Programme merekomendasikan komposisi vaksin influenza yang berlaku untuk tahun berikutnya pada bulan September dan Februari. Musim influenza pada umumnya mulai pada musim dingin bulan Mei-Juni pada belahan bumi Selatan (Southern hemisphere), dan November-Desember untuk belahan bumi Utara (Northern hemisphere).

- Negara tropis tidak memiliki musim panas dan dingin yang jelas sehingga waktu aktivitas influenza kurang dapat diprediksi, maka perlu data surveilans untuk membuat pola influenza di setiap negara. Maka untuk Indonesia dipilih vaksin (formulasi dari belahan utara atau selatan) yang diproduksi oleh produsen vaksin sesuai dengan waktu yang tepat (ditentukan oleh tanggal kadaluarsa vaksin tersebut).

\section{Rekomendasi WHO untuk 2006/2007 komposisi vaksin,}

- Belahan utara adalah, A/New Caledonia/20/ 99(H1N1)-like virus; A/Wisconsin/67/2005 (H3N2)like virus; dan B/Malaysia/2506/2004 like virus.

- Belahan selatan adalah, A/New Caledonia/20/ 99(H1N1)-like virus; A/California/7/2004(H3N2)like virus; dan B/Malaysia/2506/2004 like virus

\section{WHO position on influenza vaccine, 2002}

Rekomendasi WHO untuk vaksin influenza pada anak sebagai berikut

- Tujuan utama pemberian vaksin influenza pada anak adalah mencegah influenza berat dan komplikasinya.

- Vaksin influenza tidak mempengaruhi vaksin DPT atau vaksin lainnya

- Untuk mengurangi efek samping pada anak, vaksin influenza yang dianjurkan adalah vaksin split atau subunit

- Vaksin influenza tidak boleh diberikan pada bayi kurang dari 6 bulan
- Untuk umur 6 - 35 bulan hanya diberikan setengah dosis vaksin dewasa.

\section{Rekomendasi Advisory Committee on Immunization Practices (ACIP), 2006}

Advisory Committee on Immunization Practices memberikan rekomendasi untuk pemberian vaksin influenza pada anak sebagai berikut,

- Vaksin inflenza diberikan pada anak umur 6 bulan 5 tahun pada semua anak usia tersebut, tidak hanya untuk anak-anak dengan risiko tinggi (asma, penyakit jantung, sickle cell anemia, HIV) seperti rekomendasi tahun 2003.

- Komite juga merekomendasikan vaksinasi rutin untuk kontak serumah dan pekerja sosial yang berhubungan dengan perawatan/pendidikan anak yang berumur 24-59 bulan

- Implementasi pemberian imunisasi influenza pada anak dimulai pada musim gugur tahun 2004 ,

- Vaksin influenza tidak boleh untuk anak $<6$ bulan,

- Pada anak yang tidak divaksinasi pada umur kurang dari 9 tahun, perlu diberikan imunisasi 2 dosis dengan jarak pemberian lebih dari 1 bulan,

- Pada vaksinasi tahunan berikutnya hanya diberikan 1 dosis, karena telah terjadi penurunan kekebalan dan komposisi virus yang bersirkulasi berubah,

- Vaksin tahun sebelumnya tidak boleh diberikan untuk tahun sekarang.

\section{Rekomendasi Satgas Imunisasi IDAI}

Rekomendasi Satgas Imunisasi IDAI mengenai pemberian vaksin influenza pada anak mengacu pada rekomendasi Advisory Committee on Immunization Practices (ACIP) 2006, American Academy of Pediatrics (AAP), American Academy of Family Physicians (AAFP) 2006 dan WHO:

- Vaksinasi influenza diberikan pada bayi dan anak sejak umur 6 bulan atau lebih pada semua individu tidak memandang ada tidaknya faktor risiko.

- Orang yang berhubungan dengan perawatan/ pendidikan anak (termasuk penghuni serumah) yang berhubungan dengan kelompok anak usia 2459 bulan (ACIP 2006)

- Dosis vaksin: vaksin influenza intramuscular trivalent inactivated influenza (TIV) dianjurkan diberikan dengan dosis yang tepat menurut umur sebagai berikut,

- Umur 6-35 bulan : 0,25ml

- Umur $^{3} 3$ tahun : 0,50 ml 
- Umur kurang dari 9 tahun yang mendapat vaksin influenza (TIV) untuk pertama kali, harus mendapat 2 dosis dengan interval minimal 4 minggu.

- Cara pemberian: vaksin influenza diberikan secara intramuskular pada paha anterolateral atau deltoid

- Pemberian vaksin influenza diulang setahun sekali kapan saja namun dianjurkan pada bulan September-Oktober (3 bulan sebelum puncak prevalensi influenza)

- Indikasi kontra pemberian vaksin influenza adalah alergi terhadap komponan vaksin (misalnya telur) dan penyakit infeksi berat disertai atau tanpa demam.

- Perhatian khusus pada anak yang mempunyai riwayat menderita sindrom Guillain-Barre pasca imunisasi influenza.

\section{Penutup}

Infeksi virus influenza pada anak lebih berat dari pada dewasa, karena cenderung terjadi komplikasi. Kelompok rentan terjadi pada anak usia di bawah 2 tahun. Vaksin influenza trivalent inactivated influenza (TIV) diberikan pada bayi dan anak sejak umur 6 bulan atau lebih tanpa memandang ada tidaknya faktor risiko. Untuk Indonesia, vaksin influenza TIV dapat diberikan kapan saja namun terbaik pada bulan September - Oktober.

\section{Daftar Pustaka}

1. Nicholson K. G.: Clinical features of influenza. Seminary in respiratory infections 1992; 7:26-37.

2. Yuwono D, Putranto RH, Heriyanto B, Wahyuhono G, Nur K, Apsari H. dkk. Surveilans epidemiologi influenza Jabotabek. Progress report penelitian. Badan Penelitian dan Pengembangan Departemen Kesehatan, 2006.

3. Kartasamita CB. Vaksin influenza. Dalam: Pedoman imunisasi di Indonesia, Ranuh IGD, Suyitno H, Hadinegoro, SR, Kartasasmita CB., penyunting. Edisi kedua. Satgas Imunisasi IDAI, Jakarta 2004. h. 14352 .

4. Red book, report of the committee on infectious diseases. Influenza. American Academy of Pediatrics. Illinois; Amerika Serikat, 2003.

5. Paladin FJ. Influenza virus surveillance. PSMID Annual Convention, 2005.

6. Harper SA, Fukuda K, Uyeki TM, Cox NJ, Bridges CB. Prevention and control of influenza. Recommendation of the Advisory Committee on Immunization Practices. MMWR, CDC. 2 Juli 29, 2005/54(RR08);1-4.

7. MMWR, CDC. Update: influenza vaccine supply and recommendation for prioritization during the 05-06 influenza season. MMWR, CDC. September 2, 2005/ $54 ; 850$.

8. ACIP. New ACIP Recommendations. February 2006.

9. Influenza Asian Focus. Influenza vaccine recommendations in the Asia-Pasific region. Influenza Asian Focus 2006:2;5. 